\title{
Genetic variability studies for yield, yield attributing and fibre quality traits in cotton (Gossypium hirsutum L.)
}

\author{
Shruti $^{1^{*}}$, H. C. Sowmya ${ }^{1}$, J.M., Nidagundi ${ }^{1}$, R. Lokesha ${ }^{1}$, \\ B. Arunkumar ${ }^{1}$ and M. Shankar Murthy ${ }^{2}$ \\ ${ }^{1}$ Department of Genetics and Plant Breeding, ${ }^{2}$ Department of Entomology, University of \\ Agricultural Sciences, Raichur-584101, Karnataka, India \\ *Corresponding author
}

Keywords

Cotton (Gossypium hirsutum),

Genotypic

coefficient of

variation $(\mathrm{GCV})$

Phenotypic

Article Info

Accepted:

25 September 2019

Available Online:

10 October 2019

\section{A B S T R A C T}

The study was conducted during kharif, 2018 at experimental block of Agricultural College, Bheemarayanagudi to evaluate twenty upland cotton genotypes for 15 characters in a Randomized Complete Block Design. Analysis of variance revealed significant differences for all traits revealing a high degree of variability among the genotypes. Number of monopodia per plant, sympodial length at fifty per cent of plant height and number of bolls per plant showed high GCV and PCV. While upper half mean length, fibre strength, ginning outturn and micronaire showed comparatively low GCV and PCV. High heritability coupled with high genetic advance as per cent of mean were observed for plant height, number of sympodia per plant, sympodial length at fifty per cent plant height, inter-nodal length, number of bolls per plant, boll weight and lint index, indicating the existence of additive gene action hence selection on phenotypic basis might be productive. Variability studies help to determine the selection criteria for the improvement of yield and quality traits.

\section{Introduction}

Cotton is one of the most important commercial crops having profound influence on economics and social affairs of the country. It is a soft, staple fibre that grows around the seeds of cotton plant (Gossypium sp.). The cotton seed coat extends into tubular fibre which is spun into yarn. It is also called "King of fibre crops" or "White Gold" due to its global importance in agriculture as well as industrial economy. Cotton in India contributes 85 per cent of raw material to textile industry and it earns about 33 per cent of total foreign exchange (Anon, 2015).

World wide cotton is grown over an area of $33.30 \mathrm{~m}$ ha with productivity of $792 \mathrm{~kg}$ per ha as per USDA, 2018. India ranks first in global scenario (about $33 \%$ of the world cotton area). 
Average productivity of cotton in India, is low (560 kg lint per ha) when compared to the world average (792 $\mathrm{kg}$ per ha) and some of the leading producer of lint are namely, Australia (1781 kg per ha), China (1761 kg per ha), Brazil (1522 kg per ha), USA (974 kg per ha), and Pakistan (699 kg per ha).

India is the largest producer of cotton followed by China and contribute 25.4 per cent of world cotton production. Gujarat is the leading producer of cotton (92.00 lakh bales) followed by Maharastra (81.00 lakh bales) and Telangana (53.00 lakh bales). Karnataka ranks fifth in area and eighth in production with an area of 5.75 lakh heactares and a production of 18.00 lakh bales with a productivity of $532 \mathrm{~kg}$ lint per ha.

Before breeding is taken up to accomplish the prime objective in cotton improvement, it is desirable to elicit information on the extent of genetic variability present in the material. The assessment of extent of variation present in the genetic material becomes an essential step to know the magnitude of improvement that can be attained for various characters and to decide the ways to achieve it. Effectiveness of selection depends on the magnitude of genetic variability in a particular character. It is necessary to study variability in respect of quantitative characters with reference to genetic parameters such as genotypic variance, phenotypic variance, heritability and genetic advance as per cent of mean. The coefficients of variation expressed in per cent at phenotypic and genotypic levels have been used to compare the variability observed among the different characters. A wider spectrum of variability will enhance the chances of selecting a desired genotype.

Besides genetic variability, knowledge on heritability and genetic advance measures the relative degree to which a character is transmitted to progeny, there by helps the breeder to employ a suitable breeding strategy to achieve the objective quickly. GAM together with heritability estimates gives a relatively better picture of the amount of advance to be expected through selection (Johnson et al., 1955). A relative comparison of heritability values and expected genetic advance expressed as the per cent of means gives an idea about the nature of gene action governing a particular character. Therefore, for successful improvement of any crop, it is necessary to have a thorough knowledge on the variability present in the available breeding material.

\section{Materials and Methods}

The experimental material consist of 20 genotypes, collected from Main Agricultural Research Station, Raichur. The experimental material was sown in Randomised Complete Block Design with three replications during kharif, 2018 at experimental block of Agricultural College, Bheemarayanagudi. 4 rows of each $6 \mathrm{~m}$ length were assigned to each genotype with plants having $90 \times 30 \mathrm{~cm}$ spacing. Five plants were randomly selected from each replication in each genotype and the average value was computed for plant height, number of monopodia, number of sympodia, sympodial length at ground level, sympodial length at 50 per cent plant height, upper half mean length, lint index and seed cotton yield.

\section{Results and Discussion}

The ANOVA for yield, yield attributing and fibre quality traits for the present study is presented in Table 2. Among the 15 characters studied, all the characters exhibited significant values for genotypes indicating that the genotypes were genetically different for mean values further one can also opine that variability among genotypes was significant. Wide range of variation provides ample scope for selection of superior and desirable 
genotypes by plant breeders for further improvement using these characters. The mean data and range for different traits across the genotypes are presented in Table 2 . variability parameters for different traits across the genotypes are presented in Fig 1and 2.

Plant height registered a wide range of 91.00 $\mathrm{cm}$ (RAH 14119) to $145.00 \mathrm{~cm}$ (RAH 1075) with a mean value of $109.98 \mathrm{~cm}$. The wide range indicates the relevance of choosing plant height as parameter in characterising the genotypes into compact and robust classes. Moderate GCV (12.57\%) and PCV (13.73\%) values were observed for this trait and the narrow difference between them indicates that, most of the variability observed was due to the predominance of genotype in the ultimate expression of its phenotype. Similar reports were presented by Abbas et al., (2013), Pujer et al., (2014), Latif et al., (2015) and Dahiphale et al., (2015). High heritability $(83.76 \%)$ coupled with high genetic advance as per cent of mean (23.69\%) was observed for plant height. It was in accordance with the findings of Vinodhana et al., (2013), Pujer et al., (2014), Naik et al., (2016), Shao et al., (2016), Khokher et al., (2017) and Adsare and Salve (2017).

The number of monopodia per plant ranged from 0.80 (RAH 14158) to 1.80 (BGDS 10633 ) with a mean of 1.36. The estimates of GCV (20.13\%) and PCV (26.88\%) were high. Moderate heritability (56.09\%) coupled with high genetic advance as per cent of mean $(31.06 \%)$ was observed for this trait. The GCV and PCV values were found to be higher and the difference between them is high indicating a major influence of environment over the phenotypic development of the trait. The results were in confirmation with those reported by Vineela et al., (2013), Latif et al., (2015), Dahiphale et al., (2015), Naik et al., (2016) and Khokher et al., (2017).
The mean value of number of sympodia per plant is 22.25. Lowest number of sympodia were observed in BGDS 1063-3 (15.50) and highest number of sympodia were observed in RAH 1075 (28.00). The estimates of GCV $(18.00 \%)$ and PCV (18.48\%) were moderate. High heritability $(94.84 \%)$ coupled with high genetic advance as per cent of mean $(36.11 \%)$ was observed for this trait indicating the predominance of additive gene action in controlling the trait. Similar findings were also reported by Ashokkumar and Ravikesaran (2010), Patel et al., (2013), Vinodhana et al., (2013), Dhivya et al., (2014), Ahsan et al., (2015), Latif et al., (2015), Baloch et al., (2015) and Khokher et al., (2017). Sympodial branches are fruiting branches that are very crucial deciding the yield capacity of cotton. The PCV and GCV values were moderate and their closeness points towards the weaker involvement of environment in trait expression. Observations indicating existence of considerable variability for sympodial number were reported earlier by Rao and Gopinath (2012), Vineela et al., (2013), Abbas et al., (2013), Srinivas et al., (2014) and Dahiphale et al., (2015).

Sympodial length at ground level varied from $19.33 \mathrm{~cm}$ (BGDS 1033) to $32.56 \mathrm{~cm}$ (RAH 14158 ) with a mean value of $22.80 \mathrm{~cm}$. The estimates of GCV (12.64\%) and PCV $(20.00 \%)$ were moderate. Moderate heritability $(39.79 \%)$ coupled with moderate genetic advance as per cent of mean (16.42\%) was observed for this trait. Sympodial length at ground level gives a measure of the three dimensional space occupied by the plant. Moderate heritability and GAM for the trait indicated that, selection for sympodial length at ground level will not contribute much towards the crop improvement.

Sympodial length at fifty per cent plant height ranged from $14.47 \mathrm{~cm}$ (BGDS 1063) to 31.80 cm (RAH 14119) with a mean value of 20.45 
$\mathrm{cm}$. It showed high GCV (26.60\%) and PCV $(30.72 \%)$. High heritability $(74.98 \%)$ coupled with high GAM (47.45\%) were observed for this trait. The wider range indicates the significant variability existing among the genotypes for this trait. The trait exhibited high GCV and PCV coupled with high broad sense heritability and high GAM indicating the efficiency of selection for this trait in crop improvement.

Mean value of inter nodal distance is $5.26 \mathrm{~cm}$. the trait expression ranged from $4.33 \mathrm{~cm}$ (BGDS 1033) to $6.77 \mathrm{~cm}$ (RAH 1075). The trait recorded moderate GCV (12.47\%) and high PCV (20.22\%). High heritability (68.94\%) coupled with high GAM (21.33\%) was recorded for this trait. Inter nodal distance gives an idea about the space available between fruiting branches and ultimately determines the plant height. Preetha and Raveendran (2007) reported moderate GCV and high heritability coupled with high GAM for inter nodal length.

The trait expressed large variation in terms of number of bolls per plant with values ranging from 18.00 (RAH 14254) to 39.67 (RAH $1075)$ with a mean value of 23.81 . It showed high GCV (20.60\%) and PCV (21.90\%). Similar conclusions for the trait were drawn earlier by Dinakaran et al., (2012), Vineela et al., (2013), Vinodhana et al., (2013), Dhivya et al., (2014), Pujer et al., (2014), Srinivas et al., (2014), Ahsan et al., (2015) and Dahiphale et al., (2015), Shao et al., (2016), Chaudhari et al., (2017) and Adsare and Salve (2017). High heritability (88.53\%) coupled with high GAM $(39.93 \%)$ was observed for this trait.

Similar conclusions for the trait were drawn earlier by Pujer et al., (2014), Srinivas et al., (2014), Ahsan et al., (2015), Latif et al., (2015), Shao et al., (2016), Chaudhari et al., (2017), Khokher et al., (2017) and Adsare and Salve (2017).
Boll weight ranged from $3.00 \mathrm{~g}$ (RAH 14254) to $4.17 \mathrm{~g}$ (RAH 1075) with a mean boll weight of $3.52 \mathrm{~g}$. It showed moderate GCV $(10.03 \%)$ and PCV (11.34\%). High heritability (67.23\%) coupled with high GAM (15.71\%) was recorded for this trait indicating predominance of additive gene action in controlling this trait. Hence direct selection may be effective. Similar findings were also reported by Dinakaran et al., (2012), Pujer et al., (2014), Naik et al., (2016), Adsare and Salve (2017) and Khokher et al., (2017).

The mean value Upper Half Mean Length is $28.58 \mathrm{~mm}$ with an upper limit of $31.63 \mathrm{~mm}$ (SCS 793) and a lower limit of $25.23 \mathrm{~mm}$ (RAH 14209). The estimates of GCV (5.54\%) and PCV (5.94\%) was low. High heritability $(87.50 \%)$ coupled with moderate GAM $(10.70 \%)$ was recorded for this trait. The GCV and PCV values were very low for this trait combined with small difference between GCV and PCV values indicate lesser extent of environmental influence for the development of fibre quality traits. Similar findings were reported by Dinakaran et al., (2012), Pujer et al., (2014), Srinivas et al., (2014), Dahiphale et al., (2015), Shao et al., (2016) and Chaudhari et al., (2017).

The range for variation for fibre strength was from $25.60 \mathrm{~g} / \mathrm{tex}$ (RAH 14206) to $31.60 \mathrm{~g} / \mathrm{tex}$ (RAH 14172) with a mean of $28.81 \mathrm{~g} / \mathrm{tex}$. The estimates of GCV (6.13\%) and PCV (6.28\%) were low. High heritability (95.09\%) coupled with moderate GAM (12.31\%) was recorded for this trait. Similar findings were obtained by Dinakaran et al., (2012), Pujer et al., (2014), Srinivas et al., (2014), Dahiphale et al., (2015), Shao et al., (2016) and Chaudhari et al., (2017).

High heritability coupled with moderate GAM indicated the action of both additive and non additive genes. 
Table.1 Analysis of variance for yield, yield attributing and fibre quality traits in cotton (Gossypium hirsutum)

\begin{tabular}{|c|c|c|c|c|c|c|c|c|c|c|c|c|c|c|c|c|}
\hline \multirow{2}{*}{$\begin{array}{l}\text { Source of } \\
\text { variation }\end{array}$} & \multicolumn{16}{|c|}{ Mean sum of squares } \\
\hline & DF & PH & $\mathbf{N M}$ & NS & SLG & SLFPH & INL & NBP & BW & UHML & FS & MIC & GOT & SI & LI & SCY \\
\hline Replication & 2 & 100.21 & 0.01 & 4.12 & 7.01 & 13.76 & 0.14 & 18.14 & 0.07 & 9.32 & 7.31 & 1.09 & 5.87 & 1.21 & 0.31 & 509621.45 \\
\hline Treatment & 19 & $609.98 * *$ & $0.29 * *$ & $\begin{array}{c}48.99 * \\
*\end{array}$ & $\begin{array}{c}37.49 * \\
*\end{array}$ & $98.69 * *$ & $\begin{array}{c}1.53^{*} \\
*\end{array}$ & $\begin{array}{c}75.32 * \\
*\end{array}$ & $\begin{array}{c}0.43 * \\
*\end{array}$ & $7.91 * *$ & $\begin{array}{c}9.51 * \\
*\end{array}$ & $0.31 * *$ & $\begin{array}{c}30.75 * \\
*\end{array}$ & $\begin{array}{l}2.57 * \\
*\end{array}$ & $\begin{array}{c}2.05^{*} \\
*\end{array}$ & $547609.21 * *$ \\
\hline Error & 38 & 37.02 & 0.06 & 0.87 & 12.57 & 9.87 & 0.23 & 3.11 & 0.06 & 0.36 & 0.16 & 0.08 & 7.43 & 0.36 & 0.29 & 13729.31 \\
\hline CD@5\% & & 10.06 & 0.40 & 1.54 & 5.86 & 5.19 & 0.73 & 2.92 & 0.38 & 0.99 & 0.66 & 0.45 & 4.49 & 0.99 & 0.90 & 193.68 \\
\hline
\end{tabular}

* Significant at $5 \%(P=\mathbf{0 . 0 5})$

** Significant at $1 \%(P=\mathbf{0 . 0 1})$

PH- Plant height (cm), NM- Number of monopodia, NS- Number of sympodia, SLG- Sympodial length at ground level (cm), SLFPH- Sympodial length at 50\% plant height $(\mathrm{cm})$, INL- Inter nodal length $(\mathrm{cm})$, NBP- Number of bolls per plant, BW- Boll weight $(\mathrm{g})$, UHML- Upper half mean length (mm), FS- Fibre strength, MIC- Micronaire ( $\mu \mathrm{g} / \mathrm{inch})$, GOT-Ginning outturn $(\%)$, SI-Seed index (g), LI-Lint index (g), SCY-Seed cotton yield (kg/ha) 
Table.2 Estimation of variability parameters for yield, yield attributing and fibre quality traits in cotton (Gossypium hirsutum L.)

\begin{tabular}{|c|c|c|c|c|c|c|c|c|c|}
\hline \multirow{2}{*}{$\begin{array}{l}\text { Sl. } \\
\text { NO } \\
\text {. }\end{array}$} & \multirow[t]{2}{*}{ Character } & \multirow[t]{2}{*}{ Mean } & \multicolumn{2}{|l|}{ Range } & \multicolumn{2}{|c|}{ Coefficient Variation } & \multirow[t]{2}{*}{$\mathbf{h}^{2}(\%)$} & \multirow{2}{*}{$\begin{array}{l}\text { GA } \\
(\%)\end{array}$} & \multirow{2}{*}{$\begin{array}{l}\text { GAM } \\
(\%)\end{array}$} \\
\hline & & & Minimum & Maximum & GCV $(\%)$ & $\operatorname{PCV}(\%)$ & & & \\
\hline 1 & Plant height (cm) & 109.98 & 91.00 & 145.00 & 12.57 & 13.73 & 83.76 & 26.06 & 23.69 \\
\hline 2 & Number of monopodia per plant & 1.36 & 0.80 & 1.80 & 20.13 & 26.88 & 56.09 & 42.4 & 31.06 \\
\hline 3 & Number of sympodia per plant & 22.25 & 15.50 & 28.00 & 18.00 & 18.48 & 94.84 & 8.03 & 36.11 \\
\hline 4 & Sympodial length at ground level $(\mathrm{cm})$ & 22.80 & 19.33 & 32.56 & 12.64 & 20.00 & 39.79 & 3.75 & 16.42 \\
\hline 5 & Sympodial length at $50 \%$ plant height $(\mathrm{cm})$ & 20.45 & 14.47 & 31.80 & 26.60 & 30.72 & 74.98 & 9.71 & 47.45 \\
\hline 6 & Inter nodal distance $(\mathrm{cm})$ & 5.26 & 4.33 & 6.77 & 12.47 & 20.22 & 68.94 & 1.12 & 21.33 \\
\hline 7 & Number of bolls/plant & 23.81 & 18.00 & 39.67 & 20.60 & 21.90 & 88.53 & 9.51 & 39.93 \\
\hline 8 & Boll weight $(g)$ & 3.52 & 3.00 & 4.17 & 10.03 & 11.34 & 67.23 & 55.00 & 20.01 \\
\hline 9 & Upper Half Mean Length (mm) & 28.58 & 25.23 & 31.63 & 5.55 & 5.94 & 87.50 & 3.06 & 10.70 \\
\hline 10 & Fibre strength (g/tex) & 28.81 & 25.60 & 31.60 & 6.13 & 6.28 & 95.09 & 3.55 & 12.31 \\
\hline 11 & Micronaire ( $\mu \mathrm{g} /$ inch) & 4.07 & 3.43 & 4.60 & 6.81 & 9.60 & 50.31 & 40.00 & 9.95 \\
\hline 12 & Ginning outturn (\%) & 35.54 & 30.98 & 41.85 & 7.84 & 10.97 & 51.13 & 4.10 & 11.55 \\
\hline 13 & Seed index (g) & 8.57 & 7.16 & 10.70 & 10.02 & 12.24 & 67.10 & 1.45 & 16.91 \\
\hline 14 & Lint index(g) & 4.76 & 3.51 & 6.19 & 16.09 & 19.72 & 66.58 & 1.29 & 27.04 \\
\hline 15 & Seed cotton yield (kg/ha) & 2237.65 & 1232 & 3033 & 18.85 & 19.57 & 92.84 & 837.32 & 37.42 \\
\hline
\end{tabular}

GA - Genetic advance

GAM- Genetic advance as per cent of mean 
Fig.1 Phenotypic and genotypic coefficient of variability parameters for yield, yield attributing and fibre quality traits

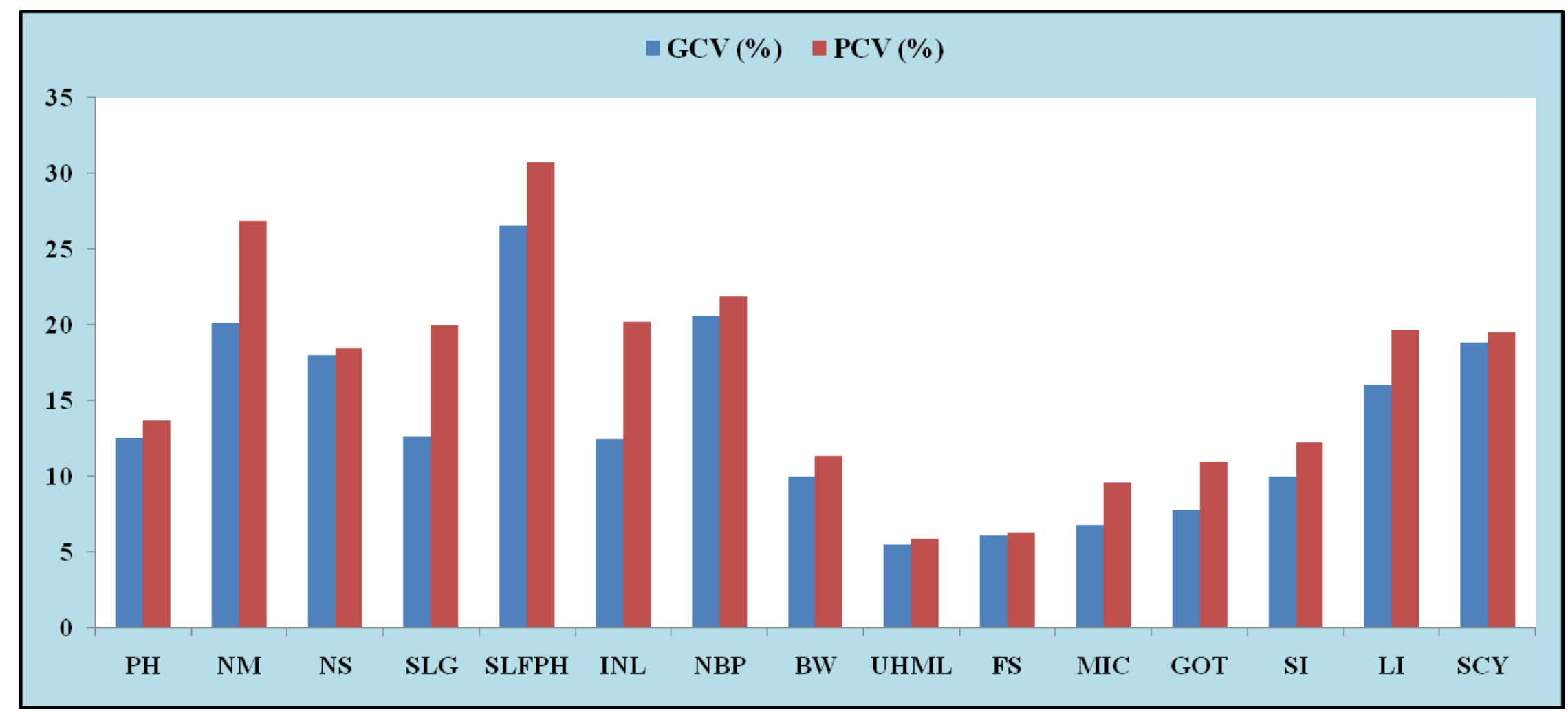

PH- Plant height (cm), NM- Number of monopodia, NS- Number of sympodia, SLG- Sympodial length at ground level (cm), SLFPH- Sympodial length at 50\% plant height $(\mathrm{cm})$, INL- Inter nodal length $(\mathrm{cm})$, NBP- Number of bolls per plant, BW- Boll weight (g), UHML- Upper half mean length (mm), FS- Fibre strength (g/tex), MIC- Micronaire ( $\mu \mathrm{g} /$ inch), GOT-Ginning outturn (\%), SI-Seed index (g), LI-Lint index (g), SCY-Seed cotton yield ( $\mathrm{kg} / \mathrm{ha})$ 
Fig.2 Heritability estimate and genetic advance as percent of mean for yield, yield attributing and fibre quality traits

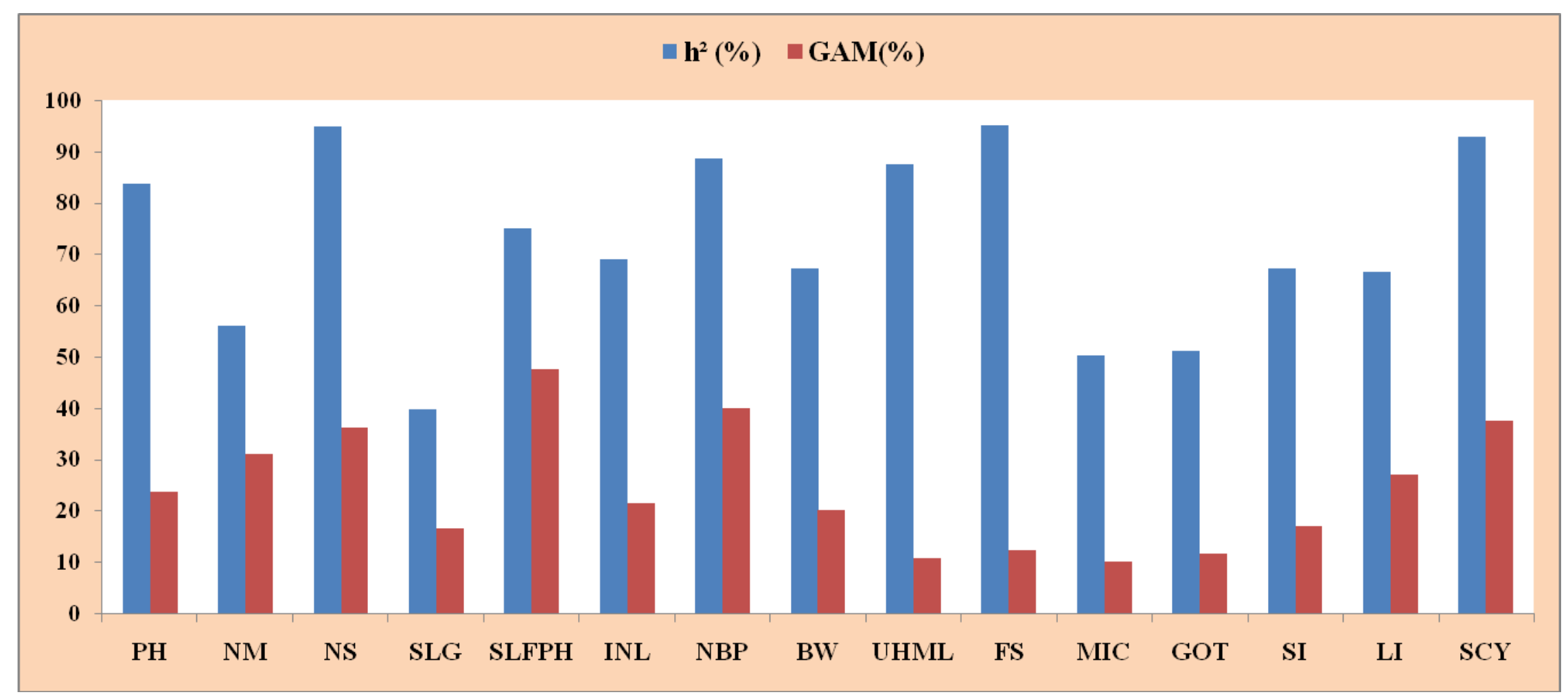

PH- Plant height (cm), NM- Number of monopodia, NS- Number of sympodia, SLG- Sympodial length at ground level (cm), SLFPH- Sympodial length at 50\% plant height (cm), INL- Inter nodal length (cm), NBP- Number of bolls per plant, BW- Boll weight (g), UHML- Upper half mean length (mm), FS- Fibre strength (g/tex), MIC- Micronaire ( $\mu \mathrm{g} /$ inch), GOT-Ginning outturn (\%), SI-Seed index (g), LI-Lint index (g), SCY-Seed cotton yield (kg/ha) 
These findings are in accordance with the results obtained by Rao and Gopinath (2012). Fibre strength plays a crucial role in the textile industry. At the time of spinning, if the fibre has higher strength, then the per cent of breakage will be low.

The mean value of micronaire was 4.07 $\mu \mathrm{g} /$ inch. Micronaire value ranged from 3.43 $\mu \mathrm{g} /$ inch (RAH 14172) to $4.63 \mu \mathrm{g} / \mathrm{inch}$ (RAH 0603). The estimates of GCV (6.81\%) and PCV $(9.60 \%)$ were low. Moderate heritability $(50.31 \%)$ coupled with low GAM (9.95\%) was recorded for this trait. Moderate value for heritability indicates little scope for improvement through selection for these traits. Srinivas et al., (2014) reported moderate heritability for fibre fineness whereas, Khokhar et al., (2017) reported low genetic advance over mean for micronaire. Extreme values of micronaire are not desirable because high micronaire value fibre is rough which will not suit fine fabric making. Lower micronaire value fibre is not appropriate for textile machines which lead to high breakage. A medium valued micronaire is always preferred.

The range of variation for ginning outturn was 30.98 (RAH 11076) to 41.85 (RAH 1075) with a mean value of (35.54). It showed low value of GCV (7.84\%) and moderate value of PCV (10.97\%). Moderate heritability $(51.13 \%)$ coupled with moderate GAM $(11.55 \%)$ was recorded for this trait. Moderate heritability and GAM estimates were observed for the trait indicating the predominance of non-additive gene interaction. Low GCV and moderate heritability and GAM were reported by Vinodhana et al., (2013), Adsare and Salve (2017), Chaudhari et al., (2017).

Mean value of seed index was $8.57 \mathrm{~g}$ with highest seed index value of $10.70 \mathrm{~g}$ (RAH 1075) and lowest value of $7.16 \mathrm{~g}$ (RAH 14119). The estimate of GCV (10.02\%) and PCV (12.24\%) were moderate. High heritability $(67.10 \%)$ coupled with moderate GAM (16.91\%) was observed for this trait. Similar results were also obtained by Preetha and Raveendran (2007), Kulkarni et al., (2011), Vinodhana et al., (2013), Dahiphale et al., (2015).

Lint index ranged from 3.51 (RAH 14172) to 6.19 (RAH 14209) with a mean of (4.76). The estimate of GCV (16.09\%) and PCV (19.72\%) were moderate. High heritability $(66.58 \%)$ coupled with high GAM (27.04\%) were observed for this trait. Lint index is a direct indicator of ginning outturn and fibre yield. High heritability coupled with high genetic advance featured this trait indicating the preponderance of additive gene action making selection effective. Similar results were given by Preetha and Raveendran (2007) and Suresh et al., (2017).

The genotypes exhibited large variation for seed cotton yield with highest being (RAH 1075) $(3033 \mathrm{~kg} / \mathrm{ha})$ and the lowest being (SCS 1061) (1232 kg/ha) with a mean value of $(2237.65 \mathrm{~kg} / \mathrm{ha})$. The estimate of GCV (18.85\%) and PCV (19.57\%) were moderate. High heritability $(92.84 \%)$ coupled with high GAM (37.42\%) were observed for this trait. The wide range may be due to difference in population densities observed among the genotypes and variable expression of yield traits. The micro environmental factors such as moisture availability, pest attack and disease incidence may also have contributed towards the variability for yield expression across the genotypes studied. The trait, seed cotton yield lacked the expected genetic variability judged by its moderate genotypic coefficient of variation and phenotypic coefficient of variation. This indicated that this trait does not contribute much to the total variability and there is less scope for improvement through direct selection for this trait. The results were in conformation with the findings of Patel et al., (2013) and Vineela et al., (2013). GAM together with heritability 
gives a relatively better picture of the amount of advance to be expected through selection (Johnson et al., 1955). Hence the genotypes in the present experiment have good possibilities for improvement in seed cotton yield through selection. Similar reports on high heritability and high GAM were given by Rao and Gopinath (2012), Vinodhana et al., (2013), Dhivya et al., (2014), Pujer et al., (2014), Khokher et al., (2017) and Suresh et al., (2017).

Success in cotton breeding is predominantly based on the selection and use of promising genotypes followed by assortment for favourable genes and gene complexes. The information regarding genetic variability and potential of genotypes, heritability in desirable traits provides reliable basis for the crop improvement. Genetic variability among all the 20 genotypes under study was assessed for yield, its component and fibre quality traits. Study revealed that, number of monopodia per plant and sympodial length at fifty per cent of plant height showed high GCV and PCV among others. While UHML, showed comparatively low GCV and PCV. The high heritability coupled with high genetic advance as per cent of mean were observed for plant height, number of sympodia per plant, sympodial length at fifty per cent plant height and lint index. This indicates that selection can be resorted for the improvement of these characters in the future crop improvement programmes. Among the 20 genotypes, RAH 1075 is highest yielder $(3033 \mathrm{~kg} / \mathrm{ha})$ followed by RAH 14209 (2968 kg/ha). These genotypes can be retested for productivity and stability by conducting multilocation trials over years. While comparing the fibre quality traits, SCS $793(31.63 \mathrm{~mm})$ and RAH $0603(31.40 \mathrm{~mm})$ for UHML, RAH 14172 (31.60 g/tex) and SCS 1062 (31.47 g/tex) for fibre strength, RAH $14172(3.43 \mu \mathrm{g} /$ inch) and RAH 1071 (3.60 $\mu \mathrm{g} / \mathrm{inch})$ for fibre fineness were found superior to other genotypes. Thus these genotypes for fibre quality can be used in hybridization programme.

\section{References}

Abbas, H. G., Mahmood, A., and Ali, Q., 2013, Genetic variability, heritability, genetic advance and correlation studies in cotton (Gossypium hirsutum L.). Int. Res. J. Microbiol., 4(6): 156-161.

Adsare, A. D. and Salve, A. N., 2017, Study on genetic variability for the quantitative traits in some genotypes of upland cotton (Gossypium hirsutum L.). Biosci. Discov., 8(3): 365-368.

Ahsan, M. A., Majidano, M. S., Bhutto, H., Soomro, A. W., Panhwar, F. H., Channa, A. R. and Sial, K. B., 2015, Genetic variability, coefficient of variance, heritability and genetic advance of some Gossypium hirsutum L. accessions. J. Agric. Sci., 7(2): 147-151.

Anonymous, 2015, Annual report. All India Coordinated Research Project on Cotton.

Ashok Kumar, K. and Ravikesavan, R., 2010, Genetic studies of correlation and path coefficient analysis for seed oil, yield and fibre quality traits in cotton ( $G$. hirsutum L.). Aust. J. Basic and Appl. Sci., 4(11): 5496-5499.

Baloch, A. W., Baloch, M., Jatoi, S. H., Baloch, M. J., Baloch,G. M., Mugheri, M. A., Depar, M. S., Mallano, I. A.,Baloch, A. M., Gandahi, N., Baloch, I. A. and Ali, M.,2015, Genetic diversity analysis in genetically modified cotton (Gossypium hirsutum L.) genotypes. Sindh Univ. Res. Jour. (Sci. Ser.), 47(3):527-530.

Chaudhari, M. N., Faldu, G. O. and Ramani, H. R., 2017, Genetic variability, correlation and path coefficient analysis in cotton (Gossypium hirsutum L.). Adv. Biores., 8(6): 226-233.

Dahiphale, K. D., Deshmukh, J. D., Bagade, A. B. and Jadhav, A. B., 2015, Studies on genetic variability, correlation and path coefficient analysis in cotton (Gossypium hirsutum L.). Int. J. Tropic. Agric., 33(1): 23-29.

Dhivya, R., Amalabalu, P., Pushpa, R. and Kavithamani, D., 2014, Variability, 
heritability and genetic advance in upland cotton (Gossypium hirsutum L.). Afr. J. Pl. Sci., 8(1): 1-5.

Dinakaran, E., Thirumeni, S. and Paramasivam, K., 2012, Yield and fibre quality components analysis in upland cotton (Gossypium hirsutum L.) under salinity. Ann. of Bio. Res., 3(8): 3910-3915.

Johnson, H. W., Robinson, H. and Comstock, R. F., 1955, Estimates of genetic and environmental variability in soybean. Agron. J., 47: 314-318.

Khokhar, E. S., Shakeel, A., Maqbool, M. A., Anwar, M. W., Tanveer, Z. and Irfan, M. F., 2017, Genetic study of cotton (Gossypium hirsutum L.) genotypes for different agronomic, yield and quality traits. Pak. $J$. Agric. Res., 30(4): 363- 372.

Latif, A., Bilal, M., Hussain, S. B. and Ahmad, F., 2015, Estimation of genetic divergence, association, direct and indirect effects of yield with other attributes in cotton (Gossypium hirsutum L.) using bi-plot correlation and path coefficient analysis. Trop. Pl. Res., 2(2): 120-126.

Naik, B. M., Satish, Y. and Babu, D. R., 2016, Genetic diversity analysis in American cotton (Gossypium hirsutum L.). Electron. J. Plant Breed., 7(4): 1002-1006.

Patel, S. M., Patel, N. A., Parmar, M. B., Patel, M. P. and Patel, J. A., 2013, Studies on variability parameters, correlation and path coefficient analysis in $B t$ cotton hybrids $(\mathrm{H}$ x H). Crop Res. HISAR, 46(1-3): 212-216.

Preetha, S. and Raveendran, T. S., 2007, Genetic variability and association analysis in three different morphological groups of cotton (Gossypium hirsutum L.). Asian J. Plant Sci., 6: 122-128.

Pujer, S., Siwach, S. S., Deshmukh, J., Sangwan, R, S. and Sangwan, O., 2014, Genetic variability, correlation and path analysis in upland cotton (Gossypium hirsutum.L.). Electron. J. Plant. Breed., 5(2): 284-289.

Rao, P. J. M., and Gopinath, M., 2012, Variability and association studies for yield and yield components in upland cotton (Gossypium hirsutum L.) under red chalka soils. Electronic J. Plant Breed., 4(1): 1093-1096.

Shao, D., Wang, T., Zhang, H., Zhu, J. and Tang, F., 2016, Variation, heritability and association of yield, fibre and morphological traits in a near long staple upland cotton population. Pak. J. Bot., 48(5): 1945-1949.

Srinivas, B., Bhadru, D., Brahmeswara Rao, M. V. and Gopinath, M., 2014, Genetic studies in yield and fibre quality traits in American cotton (Gossypium hirsutum L.). Agric. Sci. Dig., 34(4): 285-288.

Suresh, S. H., Ramesh, M. and Katageri, I. S., 2017, Genetic diversity studies for yield traits in upland cotton ( $G$. hirsutum L.). J. Pharmacognosy Phytochemistry, 1: 587593.

Vineela, N., Sambamurthy, J. S. V., Ramakumar, P.V. and Ratna Kumari, S., 2013, Variability studies for physiomorphological and yield components traits in American cotton (Gossypium hirsutum L.). J. Agric. and Vet. Sci., 4(3): 7-10.

USDA's Foreign Agricultural Service, 2018, Cotton: World Markets and Trade. Available online: https://apps.fas.usda.gov/psdonline/circular s/cotton.pdf. [Accessed on: 10/05/2018]

Vinodhana, N., Gunasekharan, M. and Vindhiyavarman, P., 2013, Genetic studies of variability, correlation and path coefficient analysis in cotton genotypes. Int. J. Pure. Appl. Biosci., 1(5): 6-10.

\section{How to cite this article:}

Shruti, H. C. Sowmya, J.M., Nidagundi, R. Lokesha, B. Arunkumar and Shankar Murthy M. 2019. Genetic variability studies for yield, yield attributing and fibre quality traits in cotton (Gossypium hirsutum L.). Int.J.Curr.Microbiol.App.Sci. 8(10): 2677-2687. doi: https://doi.org/10.20546/ijcmas.2019.810.309 